\title{
Acromegaly Associated with Multiple Tumors
}

\author{
Naoko Sekizawa ${ }^{1}$, Eri Hayakawa ${ }^{1}$, Kyoichiro Tsuchiya ${ }^{1}$, Takanobu Yoshimoto ${ }^{1}$, \\ Takumi Akashi ${ }^{2}$, Takeshi Fujii ${ }^{3}$, Shozo Yamada ${ }^{4}$ and Yukio Hirata ${ }^{1}$
}

\begin{abstract}
A 56-year-old man was admitted to our hospital for the surgical removal of renal cell carcinoma (RCC). He was diagnosed with acromegaly due to his characteristic clinical features, endocrine data, and the presence of pituitary tumor. He was found to have colon cancer and follicular thyroid tumor. Pathological examination of the pituitary tumor after transsphenoidal surgery was compatible with growth hormone (GH)secreting pituitary adenoma. We also detected the transcripts and/or immunoreactivity of GH/insulin-like growth factor I components in the tumor specimen. This is a rare case of acromegaly associated with multiple tumors, including RCC, colon cancer and thyroid tumor.
\end{abstract}

Key words: acromegaly, renal cell carcinoma, colon cancer, thyroid tumor

(Inter Med 48: 1273-1278, 2009)

(DOI: 10.2169/internalmedicine.48.1916)

\section{Introduction}

It has been well recognized that insulin-like growth factor I (IGF-I) plays an important role in the development of malignant tumors, such as colorectal, breast, and lung cancer (1-4). Several clinical and experimental studies have documented that increased circulating IGF-I levels as well as increased expression of IGF-I and IGF-I receptor (IGFIR) in the tumor tissues are involved in the development of these malignant tumors $(5,6)$. Furthermore, growth hormone (GH) has also been shown to be involved in the development of malignant tumors, not only by excess IGF-I production by the liver, but also by a direct effect via its GH receptor (GHR) (7). In fact, it has been reported that GH has mitogenic and anti-apoptotic effects in many tissues via GHR, which is also expressed in a variety of tumor tissues, including colorectal and breast cancer $(8,9)$.

It has been reported that acromegaly patients have an increased risk of developing malignant tumors, particularly colorectal cancer, and possibly other cancers including breast, prostate, thyroid, and hematopoietic cancers (10-12), although epidemiological studies show a wide variation of cancer-related morbidity and mortality in acromegaly (13).
However, several epidemiologic studies have shown that renal cell carcinoma (RCC) rarely occurs in acromegaly (14-16). To the best of our knowledge, cases of acromegaly associated with multiple tumors, other than in multiple endocrine neoplasia type I (MENI), have not been reported in the literature thus far.

Here, we report a case of acromegaly complicated with multiple tumors, including RCC, colon cancer, and thyroid tumor, in which local expression of IGF-I, IGF-IR, and GHR was demonstrated.

\section{Methods and Patient}

\section{Methods}

\section{Reverse transcriptase-polymerase chain reaction (RT-PCR)}

Written informed consent for the analysis of the surgical tumor specimen was obtained from the 56-year-old man patient. Total RNA was extracted from the resected colon cancer tissue using RNA zol (GIBCO/BRL, Carlsbad, CA), and cDNA synthesized using a First-Strand cDNA Syntheses Kit (Amersham Pharmacia Biotech Inc., Piscataway, NJ) accord-

\footnotetext{
${ }^{1}$ Department of Clinical and Molecular Endocrinology, Tokyo Medical and Dental University Graduate School, Tokyo, ${ }^{2}$ Department of Pathology, Tokyo Medical and Dental University Graduate School, Tokyo, ${ }^{3}$ Department of Pathology, Toranomon Hospital, Tokyo and ${ }^{4}$ Department of Hypothalamic and Pituitary Surgery, Toranomon Hospital, Tokyo

Received for publication December 3, 2008; Accepted for publication April 13, 2009

Correspondence to Dr. Yukio Hirata, yhirata.cme@tmd.ac.jp
} 
ing to the manufacturer's instructions. PCR primers were synthesized by Greiner bio-one (Tokyo, Japan). The human IGF-I primers were : sense strand $5^{\prime}$ AACAAGCCCACAGGGTATGG-3' (positions 386-405 in GeneBank accession number NM_000618.2) and antisense strand 5'-AGGGGTGCGCAATACATCTC-3' (positions 501482). The human IGF-IR primers were: sense strand 5'AGTCCTTCGCTTCGTCATGG-3’' (positions 3,710-3,729 in $\mathrm{NM}$ _ 000875.3 ) and antisense strand 5 $5^{\prime}$ GGAAGGAAGGCCTCATCTTG-3’' (positions 3,838-3,809). The human GHR primers were: sense strand $5^{\prime}$ TGGCACTGGCAGGATCAAGT-3' (positions 72-91 in NM _ 000163.2 ) and antisense strand 5' GGTGAACGGCACTTGGTGAA-3' (positions 219-200). The PCR products were examined by $1.5 \%$ agarose gel electrophoresis.

\section{Immunohistochemistry}

Immunohistochemical staining was performed on formalin-fixed, paraffin-embedded specimens of resected tumor samples by the avidin-biotin-peroxidase complex (ABC) method using an auto-staining machine (Ventana Benchmark HX System, Ventana Medical System, Tucson, AZ, USA), according to the manufacturer's protocols. Antibodies used in this study were rabbit polyclonal antibody against human GH (1:2,000 dilution, DAKO) and mouse monoclonal antibody against human IGF-IR (1:300 dilution, Lab Vision, Fremont, CA).

\section{Case Report}

A 56-year-old man visited Tokyo Medical and Dental University Hospital with hematuria and right back pain. Magnetic resonance imaging (MRI) of the abdomen revealed the presence of a large right renal mass $(10 \times 10 \times 7 \mathrm{~cm})$ (Fig. 1B, left) consistent with the diagnosis of RCC, and he subsequently underwent right nephrectomy. Microscopic examination of the resected tumor indicated clear cell carcinoma (Fig. 1B, right). During the admission, he was suspected of acromegaly due to his physical characteristics, and was transferred to our department for endocrine evaluation.

He was $168.2 \mathrm{~cm}$ tall and weighted $78.4 \mathrm{~kg}$. Blood pressure was 132/80 mmHg. He had typical acromegalic features, such as deep nasolabial furrows, macroglossia, thick lips and thickening of his hands and feet. He had noticed a progressive increase in the size of his hands and feet over 5 years and disfigurement of his face. MRI of the brain revealed the presence of a pituitary mass $(12 \times 10 \mathrm{~mm})$ (Fig. 1A, left). Laboratory data showed elevated plasma levels of GH, IGF-I and IGF binding protein 3 (IGFBP-3). Plasma levels of other pituitary hormones were within normal ranges (Table 1). Plasma $\mathrm{GH}$ did not fall below $1 \mathrm{ng} /$ $\mathrm{mL}$ (nadir $16.9 \mathrm{ng} / \mathrm{mL}$ ) after oral glucose tolerance testing (OGTT) (Table 2). Plasma GH levels decreased from 24.2 to $12.0 \mathrm{ng} / \mathrm{mL}$ after oral administration of bromocriptine $(2.5$ $\mathrm{mg}$ ), and from 24.7 to $0.85 \mathrm{ng} / \mathrm{mL}$ after subcutaneous injec- tion of octreotide $(100 \mu \mathrm{g})$. The responses of gonadotropins (LH, FSH) and PRL after LH-RH and TRH stimulation were normal, but an impaired response of TSH was found following TRH stimulation. Based on these physical, endocrine and imaging data, the diagnosis of GH-producing pituitary macroadenoma was made. The co-incidence of primary hyperparathyroidism was excluded by his normal plasma calcium and parathyroid hormone levels and the lack of parathyroid mass by ultrasonography.

As a result of the positive occult-blood of his stool and a mild anemia, colonoscopy was performed and revealed the presence of a type 2 tumor $(25 \mathrm{~mm})$ in the sigmoid colon (Fig. 1C, left). He underwent a laparoscopic colectomy prior to the transsphenoidal surgery. Pathological examination of the resected tumor was consistent with the diagnosis of well-differentiated adenocarcinoma of the colon (Fig. 1C, right).

Ultrasonography of the thyroid showed a regular-shaped and iso-hypoechoic nodule $(32.8 \times 19.6 \times 14.5 \mathrm{~mm})$ at the right lobe with a focal cystic change, surrounded by a welldefined hypoechoic capsule (Fig. 1D, left); color Doppler image showed increased blood flow within the nodule. An aspiration biopsy of the nodule revealed class III on cytopathologic examination (Fig. 1D, right). Collectively, follicular thyroid tumor was suspected and followed-up at 6-month intervals without significant changes in its size or characteristics.

He underwent transsphenoidal surgery for removal of the pituitary tumor. Microscopical examination of the resected tumor specimens was consistent with acidophilic adenoma with positive immunoreactivity for GH (Fig. 1B, right), but negative immunoreactivities for LH, FSH, TSH, ACTH, and PRL. Postoperatively, his basal GH levels remained at less than $1 \mathrm{ng} / \mathrm{mL}$, and IGF-I level became normalized (244 ng/ $\mathrm{mL}$ ), indicating the successful removal of the pituitary tumor.

RT-PCR of the patient's colon cancer tissues revealed three distinct single bands (116, 129 and 148 base pairs), corresponding to the transcripts of IGF-I, IGF-IR and GHR, respectively (Fig. 2). Immunohistochemical study also showed positive immunoreactivity of IGF-IR in the patient's renal tumor cells (Fig. 3).

\section{Discussion}

It has been well documented that acromegalic patients are susceptible to colorectal cancer and, to a lesser extent, breast and prostate cancer (10). It has also been shown that acromegaly is associated with a high prevalence of diffuse and nodular goiters $(12,17)$. However, several large-scale epidemiological studies on the incidence and prevalence of neoplastic diseases in acromegaly show very few complications of RCC (14-16). To the best of our knowledge, to date acromegaly associated with multiple tumors other than in MENI has not been reported in the literature. Therefore, this report presents a very rare case of acromegaly concomitantly 

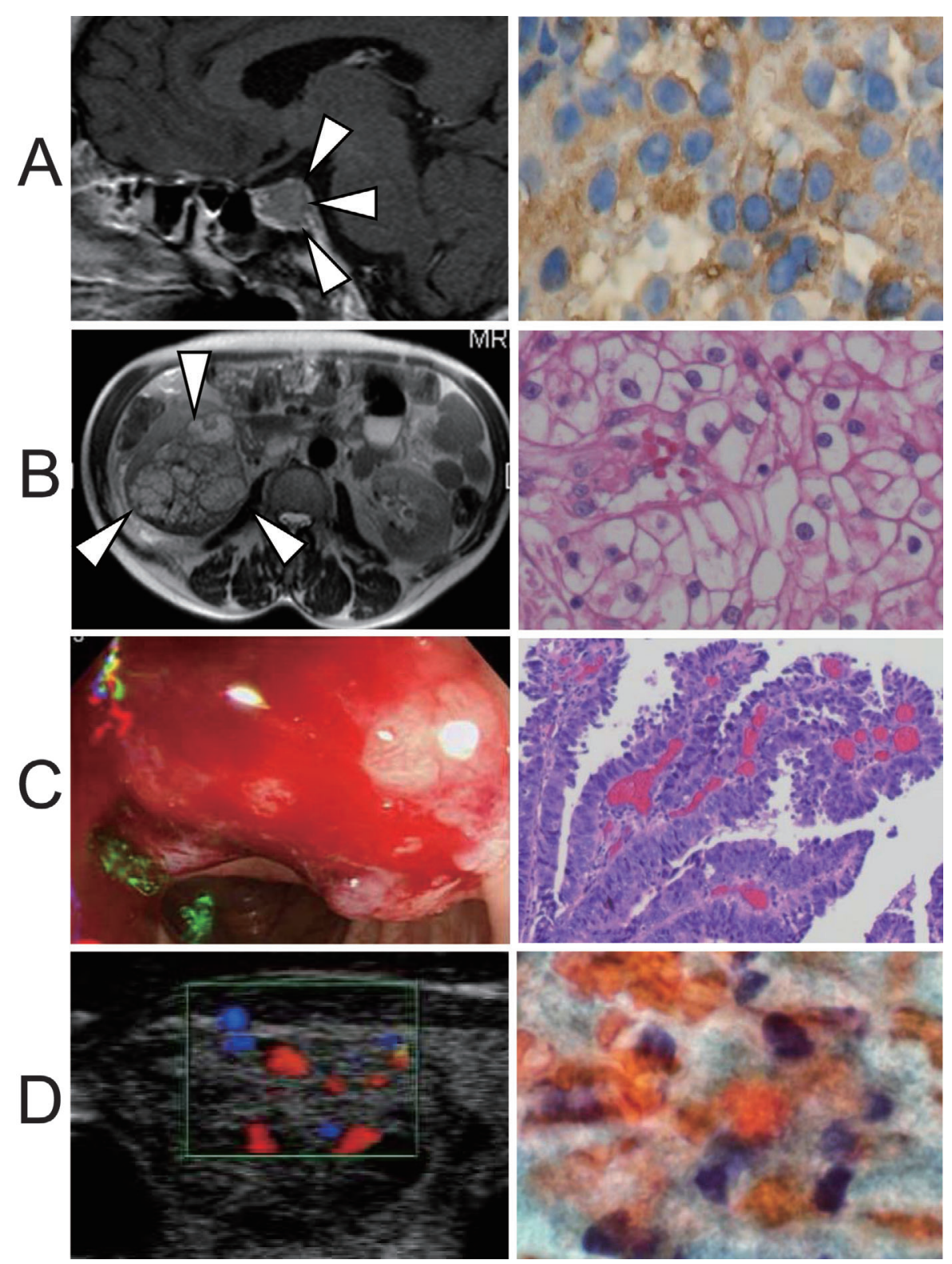

Figure 1. Diagnostic imagings and histopathology of multiple tumors in acromegaly. (A) Pituitary tumor: (left) a macroadenoma $(12 \times 10 \mathrm{~mm})$ by gadolinium-enhanced T1-weighted MRI (arrowhead), (right) immunostaining for GH, (B) renal tumor: (left) right renal tumor by T2weighted MRI (arrowhead), (right) clear cell carcinoma (Hematoxylin and Eosin staining, $\times 400$ ), (C) colon cancer: (left) type 2 sigmoid colon tumor by endoscopic examination, (right) well-differentiated adenocarcinoma (Hematoxylin and Eosin staining, $\times 200$ ), (D) thyroid tumor: (left) a nodular goiter in the right lobe by ultrasonographic examination, (right) follicular cells with denatured nuclei (oil-immersion, $\times \mathbf{1 0 0 0}$ ).

complicated with multiple tumors, including RCC, colon cancer, and thyroid tumor.

Several lines of evidence suggest that the GH/IGF-I axis plays a pivotal role in tumorigenesis in acromegaly (13). Epidemiological studies have also suggested that elevated GH/IGF-I levels are associated with the development of tumors in the general population $(1,3,4)$. To determine the possible involvement of the GH/IGF-I axis in the mechanism of the multiple tumors developed in the present case, we studied the local gene expression of each component of the GH/IGF-I axis in tumor tissues obtained from the pa- tient. We detected the mRNA transcripts of IGF-I, IGF-IR, and GH-R by RT-PCR analysis in the colon cancer tissue and positive IGF-IR immunoreactivity in the RCC tissue. Collectively, these results suggest that the augmented systemic GH/IGF-I axis due to acromegaly and the local expression of GH/IGF-I components in the tumor tissues may be involved in the process of oncogenesis and/or growth in multiple tumors in the present case.

Oncogenic processes, a cascade of activation of oncogenes and inactivation of tumor suppressor genes, have been shown to be involved in tumorigenesis (18-20). However, 
Table 1. Laboratory and Endocrine Data on Admission

\begin{tabular}{|c|c|c|c|c|c|c|c|c|c|}
\hline \multicolumn{3}{|l|}{$\underline{\text { Urinalysis }}$} & \multicolumn{3}{|l|}{ Biochemistry } & \multicolumn{4}{|l|}{ Endocrine } \\
\hline Protein & - & & Blood urea nitrogen & 13 & $\mathrm{mg} / \mathrm{dL}$ & $\mathrm{GH}$ & 15.7 & $\mathrm{ng} / \mathrm{mL}$ & $(<0.64)$ \\
\hline Glucose & - & & Creatinine kinase & 0.84 & $\mathrm{mg} / \mathrm{dL}$ & IGF-I & 1220 & $\mathrm{ng} / \mathrm{mL}$ & $(106-398)$ \\
\hline \multirow[t]{2}{*}{ Occult blood } & - & & Aspartate aminotransferase & 10 & $U / L$ & IGFBP-3 & 6.23 & $\mu \mathrm{g} / \mathrm{mL}$ & $(1.90-3.89)$ \\
\hline & & & Alanine aminotransferase & 11 & $\mathrm{U} / \mathrm{L}$ & TSH & 0.357 & $\mu \mathrm{IU} / \mathrm{mL}$ & $(0.50-5.00)$ \\
\hline$\underline{\text { Stool }}$ & & & $\gamma$-glutamyltranspeptidase & 33 & $\mathrm{U} / \mathrm{L}$ & fT3 & 2.82 & $\mathrm{pg} / \mathrm{mL}$ & $(2.3-4.3)$ \\
\hline \multirow[t]{2}{*}{ Occult blood } & $(+)$ & & Alkaline phosphatase & 287 & $U / L$ & fT4 & 1.55 & $\mathrm{ng} / \mathrm{dL}$ & $(0.90-1.70)$ \\
\hline & & & Sodium & 142 & $\mathrm{mEq} / \mathrm{L}$ & Thyroglobulin & 113 & $\mathrm{ng} / \mathrm{mL}$ & $(0-30)$ \\
\hline \multicolumn{3}{|c|}{ Complete blood count } & Potassium & 5.1 & $\mathrm{mEq} / \mathrm{L}$ & TRAb & 5.7 & $\%$ & $(0-15)$ \\
\hline White blood cells & 5900 & $/ \mu \mathrm{L}$ & Chloride & 102 & $\mathrm{mEq} / \mathrm{L}$ & $\operatorname{TgAb}$ & 0.3 & $\mathrm{U} / \mathrm{mL}$ & $(0-0.2)$ \\
\hline Red blood cells & 399 & $\times 10^{4} / \mu \mathrm{L}$ & Calcium & 10.5 & $\mathrm{mg} / \mathrm{dL}$ & TPOAb & $<0.1$ & $\mathrm{U} / \mathrm{mL}$ & $(0-0.2)$ \\
\hline Hemoglobin & 11.7 & $\mathrm{~g} / \mathrm{dL}$ & Phosphorus & 5.0 & $\mathrm{mg} / \mathrm{dL}$ & ACTH & 32 & $\mathrm{pg} / \mathrm{mL}$ & $(7-56)$ \\
\hline Hematocrit & 35.5 & $\%$ & C-reactive protein & 0.3 & $\mathrm{mg} / \mathrm{dL}$ & Cortisol & 10.49 & $\mu \mathrm{g} / \mathrm{dL}$ & $(6.4-21.0)$ \\
\hline MCV & 89.0 & $\mathrm{fl}$ & Iron & 28 & $\mu \mathrm{g} / \mathrm{dL}$ & Prolactin & 5.7 & $\mathrm{ng} / \mathrm{mL}$ & $(3.6-16.3)$ \\
\hline $\mathrm{MCH}$ & 29.3 & $\mathrm{pg}$ & UIBC & 430 & $\mu \mathrm{g} / \mathrm{dL}$ & $\mathrm{LH}$ & 2.9 & $\mathrm{mIU} / \mathrm{mL}$ & $(1.7-11.2)$ \\
\hline $\mathrm{MCHC}$ & 33.0 & $\%$ & Ferritin & 4.7 & $\mathrm{ng} / \mathrm{mL}$ & $\mathrm{FSH}$ & 12.7 & $\mathrm{mlU} / \mathrm{mL}$ & $(2.1-18.6)$ \\
\hline Platelets & 22.7 & $\times 10^{4} / \mu \mathrm{L}$ & Total-cholesterol & 163 & $\mathrm{mg} / \mathrm{dL}$ & Intact PTH & 26 & $\mathrm{pg} / \mathrm{mL}$ & $(10-65)$ \\
\hline \multirow[t]{6}{*}{ ESR } & 13 & $\mathrm{~mm}(1 \mathrm{hr})$ & Triglyceride & 142 & $\mathrm{mg} / \mathrm{dL}$ & HOMA-IR & 2.49 & & \\
\hline & & & HDL-cholesterol & 33 & $\mathrm{mg} / \mathrm{dL}$ & & & & \\
\hline & & & Fasting plasma glucose & 102 & $\mathrm{mg} / \mathrm{dL}$ & $\underline{\text { Tumor marker }}$ & & & \\
\hline & & & Hemoglobin A1c & 5.6 & $\%$ & CEA & 1.3 & $\mathrm{ng} / \mathrm{mL}$ & $(0-5.0)$ \\
\hline & & & & & & CA19-9 & 5.7 & $\mathrm{U} / \mathrm{mL}$ & $(0-37.0)$ \\
\hline & & & & & & PSA & 0.87 & $\mathrm{ng} / \mathrm{mL}$ & $(0-4.0)$ \\
\hline
\end{tabular}

MCV: mean corpuscular volume, $\mathrm{MCH}$ : mean corpuscular hemoglobin, $\mathrm{MCHC}$ : mean corpuscular hemoglobin concentration, ESR: erythrocyte sedimentation rate, UIBC: unsaturated iron binding capacity, GH: growth hormone, IGF-I: insulin-like growth factor-I, IGFBP-3: insulin-like growth factor binding protein-3, TSH: thyroid stimulating hormone, fT3: free triiodothyronine, fT4: free thyroxine, TRAb: thyroid stimulating hormone receptor antibody, TgAb: anti-thyroglobulin antibody, TPOAb: anti-thyroid peroxidase antibody, ACTH: adrenocorticotropic hormone, LH: luteinizing hormone, FSH: follicule stimulating hormone, intact PTH: intact parathyroid hormone, HOMA-IR: homeostasis model assessment of insulin resistance, CEA: carcinoembryonic antigen, CA19-9: carbohydrate antigen 19-9, PSA: prostate-specific antigen

( ) normal range

Table 2. 75g Oral Glucose Tolerance Testing on Admission

\begin{tabular}{|c|c|c|c|c|c|c|c|}
\hline Time (min) & 0 & 30 & 60 & 90 & 120 & 180 & \\
\hline Glucose (mg/dL) & 98 & 136 & 166 & 121 & 114 & 125 & \\
\hline IRI ( $\mu$ IU/mL) & & 10.3 & 36.6 & 70.0 & 30.8 & 30.0 & 31.2 \\
\hline Growth hormone (ng/mL) & 17.2 & 25.8 & 26.1 & 17.9 & 16.9 & 25.4 & \\
\hline
\end{tabular}




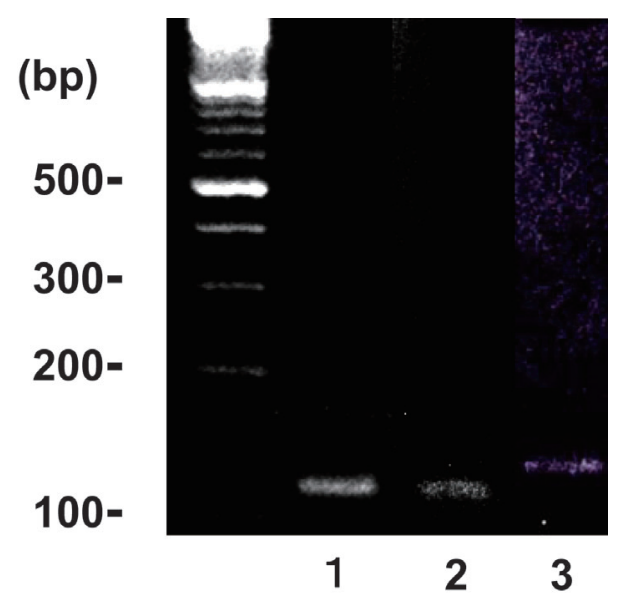

Figure 2. Gene expression of IGF-I, IGF-IR and GHR in colon cancer tissue. RT-PCR of patient's colon cancer tissue revealed three distinct bands at 116, 129 and 148 bp on $1.5 \%$ agarose gel electrophoresis, representing IGF-I (lane 1), IGFIR (lane 2) and GHR (lane 3), respectively.

little evidence from clinical and experimental studies has demonstrated that the exaggerated GH/IGF-I action is indeed involved in the oncogenic processes of multiple tumors, such as RCC, thyroid tumor and colon cancer as in the present case. On the other hand, both GH and IGF-I have been shown to induce mitogenic and anti-apoptotic effects on many tissues and cancer-derived cell lines via an endocrine and/or autocrine/paracrine manner $(7,21,22)$. Furthermore, IGF-I has been shown to affect tumor invasion or metastasis by inhibiting tumor cell attachment via Ecadherin or integrin $(23,24)$. Taken together, it is suggested that the exaggerated systemic and local GH/IGF-I axes may play a more important role in tumor growth rather than oncogenesis in acromegaly.

It remains unknown whether the augmented systemic GH/ IGF-I axis in active acromegaly is involved in the expression of IGF-IR and GHR in the tumors. Few studies on the expression levels of IGF-IR and GHR in tumor tissues from acromegalic patients have been reported, while several studies have shown increased expression of IGF-IR and/or GHR

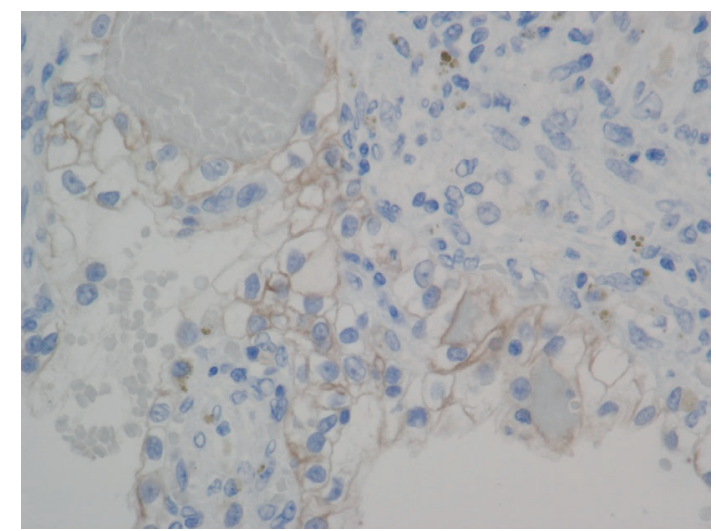

Figure 3. Immunohistochemical study of IGF-IR in renal tumor tissue. Positive immunostaining for IGF-IR in renal tumor cell is shown $(\times 400)$.

in the tumors of non-acromegalic patients $(6,8)$. It should be noted that the expression of IGF-IR is increased by activation of oncogenes, such as SV40T antigen and c-myb $(25,26)$, but decreased by activation of tumor suppressor genes, such as p53 and WT1 $(27,28)$. Thus, oncogenic transformation per se seems more likely to be responsible for the local expression of IGF-IR and GHR in the tumor tissues.

In summary, we have presented a very rare case of acromegaly associated with multiple tumors (RCC, colon cancer, and thyroid tumor). In addition to the increased circulating GH and IGF-I levels, the local expression of GHR and IGF-I/IGF-IR in the tumor tissues may partly contribute to the growth of multiple tumors.

\section{Acknowledgement}

This study was supported in part by the Grant-in-aid from the Ministry of Education, Science, Sports and Culture, and the Ministry of Health, Welfare and Labor of Japan.

A part of this study was presented at a The Third International Congress of the GRS and the IGF Society in Kobe in 2006.

\section{References}

1. Ma J, Pollak MN, Giovannucci E. Prospective study of colorectal cancer risk in men and plasma levels of insulin-like growth factor (IGF)-I and IGF-binding protein-3. J Natl Cancer Inst 91: 620625, 1999.

2. Giovannucci E, Pollak MN, Platz EA, et al. A prospective study of plasma insulin-like growth factor-1 and binding protein-3 and risk of colorectal neoplasia in women. Cancer Epidemiol Biomarkers Prev 9: 345-349, 2000.

3. Hankinson SE, Willett WC, Colditz GA, et al. Circulating concentrations of insulin-like growth factor-I and risk of breast cancer. Lancet 351: 1393-1396, 1998.

4. Yu H, Spitz MR, Mistry J, Gu J, Hong WK, Wu X. Plasma levels of insulin-like growth factor-I and lung cancer risk: a case-control analysis. J Natl Cancer Inst 91: 151-156, 1999.

5. Allison AS, McIntyre MA, McArdle C, Habib FK. The insulin- like growth factor type 1 receptor and colorectal neoplasia: insights into invasion. Hum Pathol 38: 1590-1602, 2007.

6. Ouban A, Muraca P, Yeatman T, Coppola D. Expression and distribution of insulin-like growth factor-1 receptor in human carcinomas. Hum Pathol 34: 803-808, 2003.

7. Perry JK, Emerald BS, Mertani HC, Lobie PE. The oncogenic potential of growth hormone. Growth Horm IGF Res 16: 277-289, 2006.

8. Wu X, Liu F, Yao X, Li W, Chen C. Growth hormone receptor expression is up-regulated during tumorigenesis of human colorectal cancer. J Surg Res 143: 294-299, 2007.

9. Gebre-Medhin M, Kindblom LG, Wennbo H, Tornell J, MeisKindblom JM. Growth hormone receptor is expressed in human breast cancer. Am J Pathol 158: 1217-1222, 2001.

10. Jenkins PJ. Cancers associated with acromegaly. Neuroendocrinol- 
ogy 83: 218-223, 2006.

11. Popovic V, Damjanovic S, Micic D, et al. Increased incidence of neoplasia in patients with pituitary adenomas. The Pituitary Study Group. Clin Endocrinol (Oxf) 49: 441-445, 1998.

12. Kurimoto M, Fukuda I, Hizuka N, Takano K. The prevalence of benign and malignant tumors in patients with acromegaly at a single institute. Endocr J 55: 67-71, 2008.

13. Loeper S, Ezzat S. Acromegaly: re-thinking the cancer risk. Rev Endocr Metab Disord 9: 41-58, 2008.

14. Mestron A, Webb SM, Astorga R, et al. Epidemiology, clinical characteristics, outcome, morbidity and mortality in acromegaly based on the Spanish Acromegaly Registry (Registro Espanol de Acromegalia, REA). Eur J Endocrinol 151: 439-446, 2004.

15. Orme SM, McNally RJ, Cartwright RA, Belchetz PE. Mortality and cancer incidence in acromegaly: a retrospective cohort study. United Kingdom Acromegaly Study Group. J Clin Endocrinol Metab 83: 2730-2734, 1998

16. Ron E, Gridley G, Hrubec Z, Page W, Arora S, Fraumeni JF Jr. Acromegaly and gastrointestinal cancer. Cancer 68: 1673-1677, 1991.

17. Gasperi M, Martino E, Manetti L, et al. Prevalence of thyroid diseases in patients with acromegaly: results of an Italian multicenter study. J Endocrinol Invest 25: 240-245, 2002.

18. Baldewijns MM, van Vlodrop IJ, Schouten LJ, Soetekouw PM, de Bruine AP, van Engeland M. Genetics and epigenetics of renal cell cancer. Biochim Biophys Acta 1785: 133-155, 2008.

19. Xing M. Gene methylation in thyroid tumorigenesis. Endocrinology 148: 948-953, 2007.

20. Hamilton SR. Molecular genetic alterations as potential prognostic indicators in colorectal carcinoma. Cancer 69: 1589-1591, 1992.
21. Kaulsay KK, Mertani HC, Tornell J, Morel G, Lee KO, Lobie PE. Autocrine stimulation of human mammary carcinoma cell proliferation by human growth hormone. Exp Cell Res 250: 35-50, 1999.

22. Onoda N, Ohmura E, Tsushima T, et al. Autocrine role of insulinlike growth factor (IGF)-I in a human thyroid cancer cell line. Eur J Cancer 28A: 1904-1909, 1992.

23. Playford MP, Bicknell D, Bodmer WF, Macaulay VM. Insulin-like growth factor 1 regulates the location, stability, and transcriptional activity of beta-catenin. Proc Natl Acad Sci U S A 97: 1210312108, 2000.

24. Shen MR, Hsu YM, Hsu KF, Chen YF, Tang MJ, Chou CY. Insulin-like growth factor 1 is a potent stimulator of cervical cancer cell invasiveness and proliferation that is modulated by alphavbeta 3 integrin signaling. Carcinogenesis 27: 962-971, 2006.

25. Porcu P, Ferber A, Pietrzkowski Z, et al. The growth-stimulatory effect of simian virus $40 \mathrm{~T}$ antigen requires the interaction of insulinlike growth factor 1 with its receptor. Mol Cell Biol 12: 5069-5077, 1992.

26. Travali S, Reiss K, Ferber A, et al. Constitutively expressed c-myb abrogates the requirement for insulinlike growth factor 1 in $3 \mathrm{~T} 3$ fibroblasts. Mol Cell Biol 11: 731-736, 1991.

27. Prisco M, Hongo A, Rizzo MG, Sacchi A, Baserga R. The insulinlike growth factor I receptor as a physiologically relevant target of p53 in apoptosis caused by interleukin-3 withdrawal. Mol Cell Biol 17: 1084-1092, 1997.

28. Damon SE, Plymate SR, Carroll JM, et al. Transcriptional regulation of insulin-like growth factor-I receptor gene expression in prostate cancer cells. Endocrinology 142: 21-27, 2001.

(C) 2009 The Japanese Society of Internal Medicine http://www.naika.or.jp/imindex.html 